\title{
An Example for the Construction of Masculinity in Turkey: The Woman Has No Name
}

\author{
Cansun Sebnem \\ Assistant professor, Istanbul Sabahattin Zaim University-Turkey; \\ Visiting Scholar, Brown University-U.S.A
}

doi: 10.19044/esj.2016.v13n2p62 URL:http://dx.doi.org/10.19044/esj.2016.v13n2p62

\begin{abstract}
In Turkey, the academic works on gender rather focus on Women's Studies, whilst Masculinity Studies are perceived as a relatively new research field. From this perspective, the aim of this work is to look closely at the social construction of masculinity in Turkey through the feminist author Duygu Asena's book entitled Kadının adı yok (The woman has no name). This book hit the bookstores in 1987 and had a selling record in Turkey with its forty editions within year. Duygu Asena rather depicts her male characters from a critical perspective. According to her, in the social construction of masculinity in Turkey we see that men use psychological, physical and sexual violence against women. Men criticize women, limit their liberties, beat them at times, have physical intercourse with them without necessarily asking for their consent. Even though in Turkey masculinity is actually getting modernized and we see non-traditional forms of masculinity around, we notice that hegemonic masculinity is getting reproduced in homosocial communities. We can argue that men encounter insecurity in the midst of the modernization process and suffer from the oppression related to the "male roles". We recommend that there ought to be more contributions on Masculinity Studies in Turkey.
\end{abstract}

Keywords: Masculinity construction, gender construction, feminism, Duygu Asena

\section{Introduction}

Turkish people would not necessarily know about the First, the Second and the Third Wave Feminist Movements. For instance, they would not know about the existence of the Ottoman feminist organizations and publications in the end of the 1800s (Çak1r, 1994) and about particular women such as Nezihe Muhittin (1898-1958) who fought for women's rights (Zihnioğlu, 2013). Their familiarity related to subjects such as virginity 
examinations, domestic violence, marital rape, sexual harassment, honor crimes and demands of the Islamist, Kurdish and Lesbian feminists (Sancar, 2011) come rather from here and there and from the media. However, if we were to ask Turks about "Feminism in Turkey" or "Turkish feminism" the first name that would come to people's minds would be Duygu Asena. "Turkey [considered] Duygu Asena as the most ardent defender of the feminist thought" (Hürriyet, July 30, 2006). According to Şirin Tekeli, political sociologist and one of the most important names of the Second Wave Feminist Movement, also founding president of Kadin Adaylart Destekleme ve Eğitme Derneği (Ka-Der, Association for Support and Training of Women Candidates), Asena's book The woman has no name is “Turkey’s first feminist manifesto” (T24, November 6, 2008).

When we look at the literature, we notice that the academic works written on The woman has no name are quite limited. Those works mention the impact of gender roles in the Turkish society, but they rather focus on the women's perspective. However, “femininity and masculinity are concepts that earn meanings when they are connected, and it is an obligation to look at men to understand women and to look at women to understand men" (Zeybekoğlu, 2013: 2). The works focusing on gender role in Turkey focus rather on women and the works on men and masculinity are quite rare (Kurtuluş, Uğraş, Küçükkural, 2004: 50). Therefore, our aim in this article is to focus on the social construction of masculinity in Turkey through Duygu Asena's most known work The woman has no name and to contribute to the discipline of Masculinity Studies with it.

\section{Duygu Asena and The woman has no name}

Duygu Asena (1946-2006) graduated from the Pedagogy Department of İstanbul University. After having worked in the area of her expertise, she became a journalist in the 1970s and editor-in-chief of popular women's magazines such as Kadınca (Womanly), Onyedi (Seventeen), Ev kadını (Homemaker), Bella, Kim (Who) and Negatif (Negative) (Kara, 2006: 115). We could argue that these magazines and particularly Kadınca reflect women's sensibility. It covered subjects such as “violence, sex, abortion, orgasm, feminism" and "received reaction from particularly men as well as many women” (Kara, 2006: 115).

The 1980s are the years the Feminist Movement got stronger in Turkey. Duygu Asena's book The woman has no name hit the bookstores in 1987 in this feminist era. "The book had a selling record in Turkey with its forty editions within year and then a box office record with its film version" (Şayak, 2011: 63). The same year, the Prime Ministerial Board for the Protection of Minors from Harmful Publications banned the selling of the 
book. After a case that took two years, the ban was finally off and other editions followed thereafter.

In this book, Asena mentions a woman's sexual awareness process and her individual fight against gender roles roles (Gökalp Alpaslantürk, 2015). After this book, Asena wrote other books such as Aslında aşk da yok (Actually, there is also no love), Kahramanlar hep erkek (Heroes are always men), Değişen bir şey yok (Nothing has changed), Aynada aşk vard1 (There was love in the mirror), Aslında özgürsün (Actually, you are free), Aşk gidiyorum demez (Love does not say 'I am leaving'), Paramparça (Torn in pieces). Asena's standing in Kadınca and the ideas she treated in her books makes her an important name within the Turkish feminist movement.

In June 2016, we made a search about the theses prepared on The woman has no name in the theses data bank of Yüksek Ögretim Kurulu (YÖK, Council of Higher Education) and found four particular works. They are all master theses on literature and linguistics. Ute Maria Okyar's comparison of Verena Stefan's “Hautungen” and Duygu Asena's “The woman has no name” is the oldest among those works (Okyar, 1993). This is a thesis written in German, and the system does not show any information related to it except its title. Dilek Akay, in another work prepared in German on women, compares Duygu Asena's "The woman has no name” and "Actually, there is also no love” and Elfriede Jelinek's "Die liebhaberinnen" and "Die klavierspielerin", and treats how women in the Turkish and the Austrian societies feel oppressed within family and society (Akay, 1998). Mehmet Y1lmaz, in his work in English, "A Comparative survey of the major feminine figures in T. Hardy's 'Tess of the D'Urbervilles', $\mathrm{K}$. Chopin's ‘the Awakening', G. Flaubert's 'Madame Bovary' and D. Asena's 'Kadının adı yok' from various feminist perspectives”, argues that women in those works have a common point. They all experience social oppression starting from young ages, and then, when they get liberated in time, they fight against social norms and take their revenge (Y1lmaz, 2001). Lastly, Belgin Büyük, in her work in Turkish entitled "Feminism problematic in the work 'The woman has no name' of Duygu Asena and 'Women As Lovers' of Elfriede Jelinek" focuses on women's social fight and argues that the problem has no solution (Büyük, 2010). In this last work, the author mentions the perspective of male characters as well.

There are also a few other works in the data bank of YÖK related to the author Duygu Asena. One of those works is a doctoral thesis prepared on Eastern Languages and Literatures. "A comparative study on works and literary personality of Duygu Asena and Egyptian Nevâl es-Sa'dâvî” is on the patriarchalism in the Turkish and the Egyptian societies, the oppression women suffer from and their fight against gender roles (Soyer, 2013). Among the master's theses prepared on literature and sociology, there are 
"Seducing the Demon: Women and sexuality in the trap of desire, society and memory in the novels of Erica Jong and Duygu Asena” (Kaplan, 2012), "The position of Duygu Asena in the popular feminism" (Şayak, 2011), "Comparison of main characters in terms of marriage and betrayal themes in Duygu Asena's 'Aşk Gidiyorum Demez' and Maeve Binchy's 'Tara Road'” (Kahraman, 2012), "Three generations of Turkish women through the literature of three Turkish women novelist: Duygu Asena, Erendiz Atasü and Elif Şafak" (Siakalli, 2009), "Misdirected feminism: A comparative analysis of Duygu Asena's works and prominent western feminist writings" (Arslan, 2009).

When we look at the works outside the thesis context, there are only a few works on The woman has no name. Senem Soyer, whose doctoral thesis was mentioned before, and Özlem Kale have comparisons including this book. Senem Soyer compares, through the books of Duygu Asena and Nevâl es-Sa'dâvî, Turkish and Egyptian women who suffer from social oppression and decide to fight back and survive it (Soyer, 2013). Özlem Kale, in her work entitled "Feminist readings of the novels 'The woman has no name' and 'A woman to be hanged'”, mentions the process in which women go from acceptance of social norms to disobedience (Kale, 2014). Gonca Gökalp Alpaslantürk, in "A diachronic and descriptive view to the female autographs in Turkish literature”, despite her focus on other works, mentions The woman has no name as well. According to the author, the book is may be not an auto-biography, but it is not fiction either (Gökalp Alpaslantürk, 2015).

When we look at the works prepared so far, we notice that the focus is rather on the feminist perspective and the rebellion phase of the main (female) characters. As declared earlier, we believe that it is impossible to understand men without understanding women and vice-versa. In this work, differently to previous work, we focus on how Duygu Asena describes men and men's world thanks to which we can better relate to the social realities in Turkey. To begin with, we look closely at the key experiences of Asena's characters and then we evaluate the outcome according to the current social framework of Turkey.

\section{The woman has no name and men}

Most of the men described in The woman has no name treat women badly. Men try to take advantage of women and try to keep them under their control. As a start, the main character's father is a patriarchal figure. Even though his daughters are only in primary school he puts pressure on them. For instance, he does not want them to play with boys or sit on the same row with boys. He is a man who does not want his wife and his daughters to wear pants. He enrolls his daughters in a girls' high school, barely allows them to 
enroll in the college entrance exams. Because his children are girls, he does not expect them to work and does not even consider teaching his profession to them. He always expects his wife to serve him in the household matters. We get the impression that his sex life consists of marital rape. There is also a psychological violence part that includes him asking his wife questions such as "Where are you going?”, "When are you coming back?”, “How much have you spent?” Despite his oppression on his wife and daughters, he has an extramarital affair with the neighbor Gülriz (Asena, 1987: 5, 9, 15, 23, $32,45,55)$.

The main character's husband Ci-ci (Gürkan) is a man who sexually assaults his wife on their honeymoon accusing her of acting like a child. He is a man who wants his wife to go through an abortion because he thinks they did not sufficiently hang out as a couple. After the abortion, he tells her one day "to make him a father" (Idem.: 72, 131). In essence, he seems to believe that his wife's sexual and reproductive rights are under his own control. Because he considers cooking as a woman's duty, he does not even thank her for the meals (Idem.: 78). When the main character/his wife wants to get a job, he does not support her and he almost accuses her of being a lazy person (Idem.: 96). Also, it turns out that he lies frequently. For instance, although he was only a college student he introduced himself to his future wife as a research assistant in order to impress her (Idem.: 70).

In a men's world, women encounter problems with equal pay for equal work, with the so-called "glass ceiling”. Although the main character receives a promotion and becomes a director at work, the business life described in the book is quite sexist and patriarchal. For instance, the main character and Teoman do the same job, but Teoman, who is a man, benefits from a higher salary. According to Teoman, the gap comes from the fact that "she is an eye candy" at work. He thinks that "when a woman gets recruited it is either because she is beautiful or she is the boss' mistress (...) Women cannot advance at work, they just make men happy with their looks” (Idem.: 101, 102). When Özcan, another man at work, learns that the main character will become the director of the newly founded department he accuses her of seducing the customers (Idem.: 128). Those men cannot believe that a woman could have real successes at work.

When we look at the other men in the book, we can easily consider them as patriarchal and sexist. Nilay's father is an engineer, but he is also a man who beats her daughter with wood and throws her out on the street just because she briefly talks with a boy. Also he beats his wife when she is home late (Idem.: 49). The main character's sister marries a theatre actor who is fifteen years older than she is. This man who appears to be civilized and sophisticated from the outside completely changes once the couple has children. He grows the habit of staying out late. However, he tells his wife 
that "her place is now her home" and she should not meet college mates (Idem.: 64). In the book there are also examples of men who sexually exploit women. For instance, the white haired pharmacist tells Berrin he would marry her, but it turns out that he is married with two children and has already had other extra-marital affairs (Idem.: 191). Atıf also is an example for the same kind of men. When Fügen gets pregnant he does not believe that the baby is his and leaves her alone with the baby (Idem.: 34). In short he does not take responsibility for his actions.

Kind men are almost non-existent in the book. Even when they are children, although a few of them seem to be nice and calm, they are boys who try to put their hands in girls' blouses and who try to remove their skirts. Men sitting at the coffee house give bad looks to the neighborhood girls. On a bus, a man in his thirties harasses high school girls (Idem.: 38). When the main character goes through an abortion the gynecologist caresses her leg (Idem.: 82), whereas male janitors do their best to see between her legs (Idem.: 89). Those men all seem to use their position to their advantage and to exploit women. Even "the young man with the crutches", who seems to be a nice and egalitarian man with his revolutionary character, does not know he should put his socks in the dirty laundry box and leaves his socks on the floor (Idem.: 194). Despite the well known cliché "A revolutionary would not flirt" that the activists of the 1968 movement mention, we know there is always a gap between the ideal and the reality (Mater, 2012 [2009]: 27, 144). "The young man with the crutches" has somehow shown his sentimentality and kindness by having accepted a woman in his life. However, he is a man who sulks his face when the girlfriend comes home late because of business meetings. He is a man who joins his girlfriend in concerts just because he does not want her go to concerts alone (Asena, 1987: 195).

Among all those characters, Mehmet and Aydin are the ones who can put their partner before them and hence differ from the rest of the characters. Mehmet cares about the sexual happiness of his partner. He is a man who provides her with furniture when she has her own apartment. He is the one who could think about the best birthday gift, a kitten specially brought from Van (Idem.: 121, 141). However, from an objective perspective, Mehmet is a married man with a child, who gets involved with a married co-worker (the main character of the book). Therefore, we cannot easily label him as a good man. Aydin appears to be a kind man who cares about his partner sexually speaking and who (differently to traditional Turkish men) cooks for her. However the main character just tries to estrange him before she can reveal his mistakes (Idem.: 222). When Aydin a gets a job offer in the United States he tells her "If I were you, I would come", and this seems to show that he positions a man and a woman differently in his own head (Idem.: 226). 
We can categorize Feraye's brother as a good man since he supports Fügen. After Atıf impregnates Fügen and she goes through an abortion, an elderly man wants to marry her. Since he is old and "would not understand her situation”, Feraye's brother comes up with a solution: she can earn her virginity back through surgery (Idem.: 52). In the book we do not have any other information about this brother who supports and guides the girls. Shortly put, Duygu Asena describes men in such a way that we can easily criticize them all.

\section{Masculinity Studies, the construction of masculinity in Turkey and The woman has no name}

According to "the modernizing official discourse" in Turkey, "the traditional masculinity and women's oppression” show the underdevelopment of the country (Alemdaroğlu \& Demirtaş, 2004: 210). This is the perspective from which Duygu Asena is looking at the femalemale relations in her book. The woman has no name is a book that heavily criticizes men, describes them as the gender that exploits women and despise them. We know that according to the Masculinity Studies it is wrong to talk about one type of masculinity (Sancar, 2013: 27). However because the book looks at men with a rather negative perspective, in our evaluation of the social construction of men, we proceed also in a similar perspective.

Among the few works prepared on Masculinity Studies in Turkey, we can enumerate the political scientist Serpil Sancar's Erkeklik: imkansiz iktidar: Ailede, piyasada ve sokakta erkekler (Domination and masculinity: Men in families, market and streets), where Sancar talks about men within the family, business life and on the street (Sancar, 2008); the sociologist Özge Zeybekoğlu's master's thesis Toplumsal cinsiyet bağlamında erkeklik olgusu (The perception of masculinity within the context of gender) where Zeybekoğlu draws attention to the socialization process in our society (Zeybekoğlu, 2013); the special issue "Masculinity" of Toplum ve Bilim Dergisi (Society and Science Journal, 11, Fall 2004) on the construction of masculinity through the socialization process. Also Eleştirel Erkeklik Incelemeleri Inisiyatifi (ICSM, Initiative for Critical Studies of Masculinity), Ankara University's Women's Studies Center, İzmir University’s Women's Studies Center and Stony Brook University's Center For The Study of Men and Masculinities, Açık Toplum Vakfi (Open Society Foundation) and Siyah Pembe Üçgen İzmir Derneği (Black Pink Triangle İzmir Foundation) organized "The 1st international symposium on men and masculinities" in İzmir, on September 11-13, 2014, and İstanbul Arel University organized “The masculinities/manhoods symposium” on May 7-8, 2015.

In Turkey, we could easily define men through patriarchal social values and hegemonic masculinity. Men make an effort to prove their 
masculinity incessantly. We know that patriarchal societies are the societies in which men are dominant (Buz, 2009: 55). According to the Australian sociologist Mike Donaldson, the definition of hegemonic masculinity covers heterosexuality, homophobia and men's power over women (Donaldson, 1993: 645). According to the Turkish public relations specialist Şahinde Yavuz, hegemonic masculinity "idealizes a male identity that legitimizes patriarchal relations (...) The particularities of a hegemonic masculinity are power, command, authority, distance from sentimentality, heterosexuality, homophobia, competitiveness, job owning, preoccupation with sports, sexual activity and risk taking” (Yavuz, 2014: 112). This description refers to a "white, middle class, heterosexual, middle aged, full time working man" (Zeybekoğlu, 2013: 70; Sancar, 2013: 27, 30).

Just the way Women's Studies focus on how women are oppressed, Masculinity Studies mention how men are oppressed. It was particularly in the 1970s that specialists working on this subject underlined how "the male role” oppresses men (Carrigan et al., 1985: 564). What oppresses men is not the other gender / women but it is "the male role" (Zeybekoğlu, 2013: 67). According to an American anthropologist David Gilmore, "Masculinity is created culturally and it needs to get instantly proven to the society" (Gilmore, 1987: 9; Gilmore, 1990).

In The woman has no name, men have all the qualities that fall under the category of hegemonic masculinity except homophobia and preoccupation with sports. Within the framework of "power" and “command", we can start with how men in Asena's book oppress women in their families. They look for extra-marital relations but demand virginity from their spouse. They have physical relations with women even when women do not give their consent.

We know that the Qur'an bans extra-marital sexuality both for women and men (Chabel, 2009: 32; cited by Cansun, 2013: 80). However, in practice, in Turkey, there are different sexual standards for women and men. In the daily language, expressions such as "dirt on a man's hand” or "henna on a man's hand” refers to the sexual experience men have (Tekeli, 1988: 129; cited by Cansun, 2013: 80; Atabek, 2012: 69). In fact such experience would easily go away and might even give some attractivity to men whereas the same would not be acceptable for women.

Türkiye Ekonomik ve Sosyal Etüdler Vakfi (TESEV, Turkish Economic and Social Studies Foundation) prepared a project in the beginning of 2000s on "Perceptions and mentality constructions" with the main question "What are the main expectations from femininity and masculinity". This is a representative survey on the society that is based on 72 in-depth interviews with people including "women, men, youngsters, Alevis, Kurds, members of religious congregations, high school graduates 
and illiterates" from Turkey's different cities. The results are quite informative on how people perceive the subject. The research underlines that in Turkey "honor and women's virginity have almost the same meaning" (Aksu \& Üstün, 2005: 69). According to this perspective, men do not want to be involved with women who have had an out-of-marriage relation willingly. However, they could get involved with a rape victim, since in that case, sexuality occurs without a woman's consent (Idem.: 68).

Men giving too much importance to women's virginity sometimes opens a way to the medical intervention, as it is the case in the book. Fatima Mernissi (1940-2015), Moroccan sociologist, thinks that artificial virginities and reconstructive surgery that make it possible are examples of "social schizophrenia" (Mernissi, 1982). Dilek Cindoğlu, Turkish sociologist, perceives it as “a women's survival strategy living in double standarded patriarchal gender ideologies" (Cindoğlu, 1997: 260). According to Cindoğlu, virginity in patriarchal societies does not only belong to a woman but to her family. Cindoğlu's research based on 13 in-depth interviews with gynecologists from İstanbul, Ankara and İzmir informs us that women who benefit from such a "service" come from a big spectrum, from primary school graduates to college graduates; they are rather in their late teens or early twenties; women having a high social status and earn their own salary are not interested in this "service" (Cindoğlu, 1997: 256). This last group of women are the ones who seem to break with the male oppression.

Another subject treated in the book is violence, whether it is sexual, physical or psychological. Sexual violence is an area where we cannot easily have data since it falls under the category of "familial privacy" and since people avoid talking about it. The two types of sexual violence that are most common are incest (...) and marital rape (Yüksel Oktay, 2015: 70). In a research conducted in the Gynecology Service of a university hospital in the east of Central Anatolian Region between February and April 2009, out of 200 married women, 53 percent declared that they had some sort of sexual violence at least once, 33 percent declared they had marital rape (Ípekten Alaman \& Y1ld1z, 2014). Marital rape is a crime according to the Turkish Penal Code since 2005. However it still exists as an un-inquired and unpunished crime (Armutçu, June 14, 2015). According to the United Nations' data, 1 woman out of 3 gets physical or sexual violence by her partner (United Nations, October 3, 2015) whereas according to the data of the Human Rights Association, in Turkey, every 4 hours, 1 woman is either raped or suffers from a man's violence (Milliyet, February15, 2015).

T.C. Başbakanlık kadının statüsü genel müdürlüğ̈̈ (T.R. Prime Ministry directorate general on the status and the problems of women) conducted a research between July and September 2008 on domestic violence in Turkey. According to the results, 39 percent of Turkish women 
get physical violence at some point in their lives, 15 percent get sexual violence and 44 percent get psychological violence (KSSGM, 2009). In the book the main character's spouse does not support his wife's work and accuse her of being lazy. We could consider his approach under the category of psychological violence, since such violence involves "ignorance and despise of sentimental needs such as love, compassion, care, approval, [and] support” (Yüksel Oktay, 2015: 69). "Sarcastic speech, use of words and sentences that would make one feel bad" fall also under this category (Kanal 7 , January 16, 2012). We could easily consider many words men use towards their wives in this context. Also, since in The woman has no name the husband declares his wife to be "lazy", we can also talk about "the masculinity crisis" he suffers from. The more women are active in the work life the more the patriarchal system weakens and the bread winner role of men is eradicated. Men hit insecurity through modernity, and they try to stick to the idea that "a man is the responsible person that covers the financial needs of a family". According to this perspective, in the process of modernization, traditions weaken and men become the victims of modernity (Koyuncu \& Onur, 2004: 36, 40).

The main character's father asking his wife how much money and/or time she spends outside home, his refusal of eggs boiled more or less than two minutes are subjects that we could consider as psychological violence. The members of the Yaşama Dair Araştırma Grubu (On Life Research Group) Kurtuluş, Uğraş and Küçükkural revealed similar expectations of men through their interviews. Even the weakest man in the society tries to prove his masculinity asking too much from his partner (Kurtuluş, Uğraş, Küçükkural, 2004: 68). Also the fact that men try to keep women at home has a reflection in the real life. Erdal Atabek, a Turkish psychiatrist, draws attention to the expressions hayat kadını (a life woman) and hayat erkeği (a life man). "Knowing about life" has a positive connotation for men whereas it has a negative (i.e. prostitute) connotation for women. There is not an expression sokak erkeği (a street man) but sokak kadını (a street woman), because according to the sexist approach, streets belong to men whereas women are out there only when they are prostitutes (Atabek, 2012: 172).

\section{Conclusion}

As Şirin Tekeli, political sociologist, says, Duygu Asena's book The woman has no name is Turkey's first feminist manifesto. When we look at the construction of masculinity in Turkey from the perspective of this book, we notice that men oppress women through psychological, physical and sexual violence. Men criticize women, limit their freedom, beat them and have physical intercourse with them without necessarily looking for their consent. 
Even though masculinity is actually getting modernized and we see non-traditional forms of masculinity around, hegemonic masculinity is getting reproduced in homosocial communities (Koyuncu \& Onur, 2004: 37). Masculinity Studies argue that "the male role" oppresses and victimizes men. Erdal Atabek ironically asks for a book called The man has no name. According to Atabek, we need to take into consideration men's insecurity provoked by hegemonic masculinity and their own fears (Atabek, 2012: 130).

This article aims to contribute to the Masculinity Studies literature with a perspective on the social construction of men in Turkey through Duygu Asena's book The woman has no name. The gender literature in Turkey needs more contributions on Masculinity Studies.

\section{Acknowledgments}

I would like to thank Atilla Cansun, Firdevs Gümüşoğlu and the anonymous referees for their valuable comments.

\section{References:}

1. Akay, D. (1998). Das frauenbild in den werken "Kadının Adı Yok", "Aslında Aşk da Yok" von Duygu Asena und in den werken "Die Liebhaberinnen" und "Die Klavierspielerin” von Elfriede Jelinek, Master's Thesis, Uludağ University, Bursa.

2. Alemdaroğlu, A. \& Demirtaş, N. (Fall 2004). Biz Türk erkeklerini böyle bilmezdik!: Mynet’te erkeklik halleri (This is not how we knew Turkish men! Masculinity stances on Mynet), Toplum ve Bilim, 101, 206-224.

3. Armutçu, E. (June 14, 2015). Doğuda tam 24 bin 723 kadınla yüz yüze konuştular. İşte dehşet sonuçlar (24 723 women have been talked to face-to-face in the East, here are the frightful results), Cumhuriyet, http://www.cumhuriyet.com.tr/haber/sokak/298803/Doguda_tam_2 4_bin_723_kadinla_yuz_yuze_konustular._iste_dehset_sonuclar.html (Retrieved on June 24, 2016).

4. Arslan, S. (2009). Misdirected feminism: A comparative analysis of Duygu Asena's works and prominent western feminist writings, Master's Thesis, Fatih University, İstanbul.

5. Asena, D. (1987). Kadının adı yok (The woman has no name), Afa Yayınc1lik, İstanbul.

6. Atabek, E. (2012). Kışkırtılmış erkeklik bastırılmış kadınlık (Provoked masculinity, repressed femininity), Cumhuriyet Kitapları, İstanbul. 
7. Bora, A. \& Üstün, İ. (2005). Sicak aile ortamı: Demokratikleşme sürecinde kadın ve erkekler (Warm family environment: Women and men in democratization process), TESEV Yayınları, İstanbul.

8. Buz, S. (2009). Feminist sosyal hizmet uygulamas1 (The practice of feminist social service), Toplum ve Sosyal Hizmet, 20 (1), 53-65.

9. Büyük, B. (2010). Duygu Asena'nın "Kadının Adı Yok", Elfriede Jelinek'in "Sevda Kadınları" adlı yapitlarda feminizm sorunsalı (Issue on feminism in the works of Duygu Asena's The woman has no name, Elfriede Jelinek's Women as lovers), Master's Thesis, Atatürk University, Erzurum.

10. Cansun, Ş. (2013). AKP-CHP-Kadınlar (JDP-RPP-Women), Oniki Levha Yayınc1lı, İstanbul.

11. Carrigan, T., Connell, B., Lee, J. (1985). Towards a new sociology of masculinity, Theory and Society, 14 (5), 551-604.

12. Chebel, M. (July-August 2009). La veine amoureuse en islam, Le monde des religions.

13. Cindoglu, D. (1997). Virginity tests and artificial virginity in modern Turkish medicine, Women's Studies International Forum, 20 (2), 253-261.

14. Çakır, S. (1994). Osmanlı kadın hareketi (Ottoman women's movement), Metis Yayınları, İstanbul.

15. Donaldson, M. (1993). What is hegemonic masculinity?, Theory and Society, Special Issue: Masculinities, 22(5), 643-657.

16. (Fall 2004). Erkeklik (Masculinity), Toplum ve Bilim, 101.

17. (July 30, 2006). Gazeteci Duygu Asena hayatını kaybetti (Journalist, Duygu Asena passed away), Hürriyet, http://www.hurriyet.com.tr/gazeteci-duygu-asena-hayatini-kaybetti4838807 (Retrieved on January 29, 2016).

18. Gilmore, D. (1987). Introduction: the shame of dishonor, Gilmore, D. (ed.), Honor and Shame and The Unity of The Mediterranean, A Special Publication of The American Anthropological Association, 221.

19. Gilmore, D. (1990). Manhood in the making: Cultural concepts of Masculinity, Yale University Press, New Haven \& London.

20. Gökalp Alpaslantürk, G. (2015). Türk edebiyatında kadınların özyaşamöykülerine zamandizinsel ve betimsel bir bakış (A diachronic and descriptive view to the female autographs in the Turkish literature), Türkbilig, 29, 147-160.

21. (February 17, 2015). Her 4 saatte 1 kadın tecavüze uğruyor (1 woman is raped every 4 hours), Milliyet, http://www.milliyet.com.tr/her-4saatte-1-kadin-tecavuze-gundem-2015440/ (Retrieved on June 24, 2016). 
22. İpekten Alaman, M. \& Yıldız, H. (2014). Domestic sexual violence and sexual problems among gynecology outpatients: An example from Turkey, Women \& Health, 54:5, 439-454.

23. (January 16, 2012). Kadınlar psikolojik şiddet de görüyor (Women encounter psychological violence too), Kanal 7, http://www.haber7.com/kadin/haber/831217-kadinlar-psikolojiksiddet-de-goruyor (Retrieved on June 24, 2016).

24. (November 6, 2008). Kadınlar şiddeti aile içi mesele olarak görmüyor (Women do not consider domestic violence a private family matter), T24, http://t24.com.tr/haber/kadinlar-siddeti-aile-ici-mesele-olarakgormuyor,15008 (June 24, 2016).

25. Kahraman, B. (2012). Duygu Asena'nın Aşk Gidiyorum Demez ile Maeve Binchy'nin Yalnız Kadınlar Sokağı Adlı Eserlerdeki Ana Karakterlerin Evlilik ve Aldatma Temaları Açısından Karşılaştırılması (Comparison of main characters in terms of marriage and betrayal themes in Duygu Asena's Aşk Gidiyorum Demez and Maeve Binchy's Tara Road), Master's Thesis, Eskişehir Osman Gazi University, Eskişehir.

26. Kaplan, L. C. (2012). Şeytanı baştan çıkarmak: Erica Jong ve Duygu Asena romanlarında arzu, toplum, bellek kıskacinda kadın ve cinsellik (Seducing the demon: Women and sexuality in the trap of desire, society and memory in the novels of Erica Jong and Duygu Asena), Master's Thesis, Ege University, İzmir.

27. Kara, L. (September-October-November 2006). Kadınların duygusu (The feeling of women), Hukuk Gündemi Dergisi, 115-116.

28. Kale, Ö. (July 2014). Asılacak Kadın ve Kadının Ad1 Yok romanlarında feminizmin yorumlanış1 (Interpretation of feminism in the novels The woman to be hanged and The woman has no name), Uluslararası Sosyal Araştırmalar Dergisi, 7 (32), 139-147.

29. Koç, N. (2014). Feminist kadın temsili açısından Kadının Adı Yok filminin irdelenmesi (Examination of the movie The woman has no name from a feminist representation perspective), Master's Thesis, Marmara University, İstanbul.

30. Koyuncu, B. \& Onur, H. (2004). Hegemonik erkekliğin görünmeyen yüzü: sosyalizasyon sürecinde erkeklik oluşumları ve krizleri üzerine düşünceler (The invisible face of hegemonic masculinity: thoughts on the construction of masculinity in the socialization process and crises), Toplum ve Bilim, 101, 31-49.

31. KSSGM (T.C. Başbakanlık Kadının Statüsü Genel Müdürlüğü, 2009). Türkiye'de kadına yönelik aile içi şiddet araştırması (Research on domestic violence against women in Turkey), Ankara. 
32. Kurtuluş, C., Uğraş, U. T., Küçükkural, Ö. (2004). Hegemonik erkekliğin peşinden (In pursuit of hegemonic masculinity), Toplum ve Bilim, 101, 50-70.

33. Mernissi, F. (1982), Virginity and patriarchy. Women’s Studies International Forum, 5 (2), 183-191.

34. Mater, N. (2012 [2009]). Sokak güzeldir, 68’de ne oldu? (Streets are beautiful: What happened in 68?), Metis Yayınları, İstanbul.

35. Okyar, U. M. (1993). Vergleichende Untersuchung der Romane "Hautungen" von Verena Stefan und "Kadının Adı Yok" von Duygu Asena hinsichtlich der feministischen Literaturkritik, Master's Thesis, Ankara University, Ankara.

36. Sancar, S. (2013 [2008]). Erkeklik: imkansız iktidar: Ailede, piyasada ve sokakta Erkekler (Domination and masculinity: Men in families, market and streets), Metis Yayınları, İstanbul.

37. Sancar, S. (2011). Türkiye'de Kadın Hareketinin politiği: Tarihsel bağlam, politik gündem ve özgürlükler (The politic of women's movement in Turkey: Historical context, political agenda and liberties), Sancar, S. (ed.), Birkaç Arpa Boyu... 21. Yüzyıla Girerken Türkiye'de Feminist Eleştirinin Birikimi (A short distance... the accumulation of feminist criticism in Turkey entering the 21st century), Koç Üniversitesi Yayınları, İstanbul, 53-109.

38. Siakalli, M. (2009). Three generations of Turkish women through the literature of three turkish women novelist: Duygu Asena, Erendiz Atasü and Elif Şafak, Master's Thesis, İstanbul Bilgi University, İstanbul.

39. Soyer, S. (2013). Duygu ASENA ve Nevâl es-SA’DÂVÎ eserlerinde evlilik teması ve kadın olgusu (The concept of marriage and woman in the works of Duygu ASENA and Nevâl es-SA'DÂVÎ), Nüsha, Şarkiyat Araştırmaları Dergisi, 13 (37).

40. Soyer, S. (November 1-3, 2012). Duygu ASENA ve Nevâl esSA'DÂVÎ eserlerinde kadın kahramanlar (Female heroes in the works of Duygu ASENA and Nevâl es-SA'DÂVÎ), IV. Uluslararası Karşılaştırmalı Edebiyat Bilimi Kongresi Bildiri Kitabı, 735-740.

41. Soyer, S. (2013). Misırlı Nevâl es-Sa'dâvî ile Duygu Asena'nın eserleri ve edebi kişiliklerinin karşılaştırılması (A comparative study on works and literary personality of Duygu Asena and Egyptian Nevâl es-Sa'dâvî), Doctoral Thesis, İstanbul University, İstanbul.

42. Şayak, A. M. (2011). Popüler feminizm içinde Duygu Asena'nın yeri (Duygu Asena's place in popular feminism), Master's Thesis, Muğla University, Muğla. 
43. Tekeli, Ş. (1988). Halk deyişlerinde kadınlara biçilen değer (Value given to women in folk wisdom), Tekeli, Ş. (ed.), Kadınlar için yazılar (1977-1987) (Writings for women), Alan Yayıncılık, İstanbul.

44. United Nations (October 2015). Facts and figures: Ending violence against women, http://www.unwomen.org/en/what-we-do/endingviolence-against-women/facts-and-figures (Retrieved on January 29, 2016).

45. Yavuz, Ş. (2009). İktidar olma sürecinde erkeklerin erkeklikle imtihanı (Men's masculinity put to test in the struggle for power), Millî Folklor, 26 (104), 110-127.

46. Yilmaz, M. (2001). A Comparative survey of the major feminine figures in T. Hardy's Tess of the D'Urbervilles, K. Chopin's the Awakening, G. Flaubert's Madame Bovary and D. Asena's Kadının Ad1 Yok from various feminist perspectives, Master's Thesis, Fatih University, İstanbul.

47. Yüksel Oktay, E. (2015). Türkiye'nin ve dünyanın ortak sorunu: Kadına şiddet (The common problem of Turkey and the world: Violence against women), Akademik Araştırmalar Dergisi, Sayı 64, 57-118.

48. Zeybekoğlu, Ö. (2013). Toplumsal cinsiyet bağlamında erkeklik olgusu (The phenomenon of masculinity concerning gender), Eğiten Kitap, Ankara.

49. Zihnioğlu, Y. (2013). Kadınsız inkılap (Revolution without women), Metis Yayınları, İstanbul. 